\title{
Evaluation of the effect of the application of combined pretreatments and inoculum with high alkalinity on food residues through BMP tests.
}

Edgar Daniel Alanis-Silva ( $0802206 g @ u m i c h . m x)$

Universidad Michoacana de San Nicolas de Hidalgo https://orcid.org/0000-0002-1470-0812

Ma. del Carmen Chávez-Parga

Universidad Michoacana de San Nicolas de Hidalgo

José Apolinar Cortés

Universidad Michoacana de San Nicolas de Hidalgo https://orcid.org/0000-0001-7768-3792

\section{Research Article}

Keywords: Food waste, Anaerobic Digestion, Methane, Renewable energy

Posted Date: March 8th, 2022

DOI: https://doi.org/10.21203/rs.3.rs-1408933/v1

License: (c) (i) This work is licensed under a Creative Commons Attribution 4.0 International License.

Read Full License 


\title{
Evaluation of the effect of the application of combined pretreatments and inoculum with high alkalinity on food residues through BMP tests.
}

\author{
Alanis-Silva Edgar Daniel ${ }^{1}$, Chávez-Parga Ma. Del Carmen ${ }^{1 \dagger}$ and Cortés José \\ Apolinar ${ }^{1 * \dagger}$ \\ $1^{*}$ División de Estudios de Posgrado, Facultad de Ingeniería Química, Universidad \\ Michoacana de San Nicolás de Hidalgo, Gral. Francisco J. Múgica S/N, Morelia, 58040, \\ Michoacan, Mexico. \\ *Corresponding author(s). E-mail(s): jose.apolinar@umich.mx; \\ Contributing authors: 0802206g@umich.mx; cparga@umich.mx; \\ †These authors contributed equally to this work.
}

\begin{abstract}
The management and control of food waste is currently seen as a growing concern, anaerobic digestion is a promising alternative for the valorization of food waste. This study evaluates the effect of the application of three pretreatments (grinding, $\mathrm{pH}$ control, thermal treatment) and organic load control, employing a high alkalinity inoculum for methane production through BMP tests, using a Taguchi $\mathrm{L}_{8}$ experimental design of 4 factors and 2 levels, resulting in the best performance $\left(65.91 \mathrm{NmL} \cdot \mathrm{g}^{-1}\right.$ TVS) with pretreatment conditions of grinding with fine particle size, $\mathrm{pH} 11$, thermal pretreatment at $60{ }^{\circ} \mathrm{C}$ and a concentration of $14 \mathrm{~g}$ TVS $\cdot \mathrm{L}^{-1}$, which represents an improvement of $34.66 \%$ in comparation with the food waste without pretreatments.
\end{abstract}

Keywords: Food waste, Anaerobic Digestion, Methane, Renewable energy

\section{Introduction}

At present, climate change has become a problem on a global scale. Increased temperature, changes in rainfall cycles, modifications in crops cycles, and increased drought periods are some of the results of climate change [1-3]. The main cause of climate change is the accumulation of greenhouse gases (GHG) in the atmosphere, and one of the anthropogenic sources is the organic fraction of municipal solid waste, when it degrades in landfills by anaerobic microorganisms, it produces liquid (leachates) and gaseous pollutants $\left(\mathrm{CO}_{2}\right.$,
$\mathrm{CH}_{4}$ y $\left.\mathrm{H}_{2} \mathrm{~S}\right)$. When released into the environment, these pollutants contribute to aquifer contamination and increase the concentration of greenhouse gases (GHG) [1, 2]. According to the 2021 Food waste index report, 8 to 10 percent of the GHG generated globally is related to food that was not consumed. By 2019, out of the 931 million tons of food waste generated globally, it is estimated that 26 percent (244 million tons) come from the foodservice industry, the remaining 74 percent is divided between household and retail waste. As a result, food waste generated by the food industry [5] has become an emerging problem in recent 
decades. The main components of food waste include carbohydrates, proteins, lipids, and trace inorganic components [6-8], which can be used for energy production by anaerobic processes. The biodegradability of a substrate is the main factor to know if waste biomass is eligible for anaerobic processes, which depends on its physicochemical characteristics and its composition[9]. One of the main problems encountered in the anaerobic digestion process is the destabilization of the system due to acidification, accumulation of ammonium, oils, fats, and salts, which can lead to a decrease in the process efficiency and even inhibit it [10]. The application of pretreatments to food waste has proven to be a process that generally helps improve the degradability and stability of the anaerobic process [11-13]. Based on the above, it is necessary to develop advances in the existing processes to increase the consumption of OFMSW through combined pretreatments and inoculum with high alkalinity. The combined application of pretreatments pursues the following objectives: increase in the surface area and solubilization of simple compounds by particle size reduction [14-16]; adjustment of $\mathrm{pH}$ and transformation of organic compounds by addition of strong acids or alkalis or oxidant agents [15] depending on the nature of the residue [16]; control of the concentration of the reactor feed [17, 18]. Biochemical methane potential test (BMP) tests have become important in the search for the improvement of methane and hydrogen production from waste[13, 19] because it allows the obtention of optimal conditions that influence the anaerobic digestion process in a relatively short time[19, 20]. By using this method, several factors that affect the quality of biogas can be tested, such as the substrate-inoculum (S/I) ratio, $\mathrm{pH}$, temperature, etc. [21].

\section{Anaerobic inoculum}

The anaerobic inoculum used for the BMP test is an important factor for the correct development of the test. The amount of macronutrients and trace elements is an important characteristic which has an impact on the performance of the system, and also affects the methane production.[22]

This study aims to evaluate the application of the combined pretreatment process and concentration control on the production of methane generated from the catering industry waste through
BMP tests, employing an inoculum with high alkalinity content (higher than $50 \mathrm{~g} \mathrm{CaCO}_{3} \cdot \mathrm{L}^{-1}$ ).

\section{Materials and methods}

\subsection{Food waste}

Food waste (substrate) was obtained from a restaurant located at coordinates $\left(19^{\circ} 42^{\prime} 23.7^{\prime \prime} \mathrm{N}\right.$ $101^{\circ} 10^{\prime} 25.3$ "W) that specializes in fish and seafood. The waste collection process was carried out by collecting three $2.6 \mathrm{~L}$ samples during a $10 \mathrm{~h}$ work period, then they were blended to obtain a representative sample of the waste generated. The residues were preserved at $4{ }^{\circ} \mathrm{C}$ for $24 \mathrm{~h}$ before being processed and their characterization was accomplished according to parameters and methods established in Table 1.

\subsection{Inoculum}

The inoculum used for the test was obtained from an anaerobic reactor for wastewater treatment, located in the city of Morelia, Michoacán at coor-

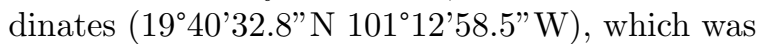
subjected to an enrichment process using a pig manure suspension ( $8 \%$ total solids) for 45 days [23]. This suspension was mixed with $\mathrm{CaO}$ at a rate of $2 \mathrm{~g} \mathrm{CaO} \cdot \mathrm{L}^{-1}$ of suspension to improve the characteristics of the inoculum (total alkalinity, alpha ratio); the inoculum was fed with this suspension every 7 days. Once the inoculum was enriched, it was sieved (Tyler mesh No. 18) to remove inert matter present in the mixture.

\subsection{Experimental design and pretreatment process}

The experimental design implemented was a Taguchi $\mathrm{L}_{8}$ orthogonal arrangement (Table 2), which contemplates four factors: three pretreatments and feed concentration control, with two levels, as shown in Table 2, obtaining a total of 8 experimental conditions (Table 3 ). Additionally, an inoculum blank was considered, as well as two residue blanks (one for each of the feed concentrations). Each of the tests was carried out in duplicate, giving a total of 22 experimental units (EU).

Type I grinding was performed in an Oster ${ }^{\circledR}$ blender model BLSTUG6648B-013, and type II, in a manual disc mill with an opening of $6 \mathrm{~mm}$. 
Table 1 Characterization tests for inoculum and residue.

\begin{tabular}{ccccc}
\hline Parameter & Units & Method/Norm & Inoculum & Waste \\
\hline pH & $\mathrm{N} / \mathrm{A}$ & APHA & $\mathrm{X}$ & $\mathrm{X}$ \\
Conductivity & $\mathrm{mS} \cdot \mathrm{cm}^{-1}$ & APHA & $\mathrm{X}$ & $\mathrm{X}$ \\
Alkanity & $\mathrm{mg} \mathrm{CaCO} 3 \cdot \mathrm{L}^{-1}$ & APHA & $\mathrm{X}$ & $\mathrm{X}$ \\
Solids & $\mathrm{mg} \cdot \mathrm{L}^{-1}$ & $\mathrm{APHA}$ & $\mathrm{X}$ & $\mathrm{X}$ \\
COD & $\mathrm{mg} \cdot \mathrm{L}^{-1}$ & Method $8000 \mathrm{HACH}$ & $\mathrm{X}$ & $\mathrm{X}$ \\
Total Nitrogen & $\mathrm{mg} \cdot \mathrm{L}^{-1}$ & Method 10242 HACH & $\mathrm{X}$ & $\mathrm{X}$ \\
Total Phosphorus & $\mathrm{mg} \cdot \mathrm{L}^{-1}$ & Method 10127 HACH & $\mathrm{X}$ & $\mathrm{X}$ \\
C, H, O, N, S & $\%$ & LECO's Method & $\mathrm{X}$ & $\mathrm{X}$ \\
Humidity & $\%$ & Gravimetric & & $\mathrm{X}$ \\
Alpha ratio & $\mathrm{N} / \mathrm{A}$ & Volumetric & $\mathrm{X}$ & \\
\hline
\end{tabular}

${ }^{\mathrm{a}}$ Chemical Oxygen Demand

Table 2 Taguchi experimental design for the BMP test.

\begin{tabular}{ccc}
\hline \multirow{2}{*}{ Factor } & $\begin{array}{l}\text { Level } \\
\text { Low }\end{array}$ & High \\
\cline { 2 - 3 } & & \\
\hline Concentration $\left(\mathrm{g}\right.$ TVS $\left.\cdot \mathrm{L}^{-1}\right)$ & 7 & 14 \\
Mechanic (Type) & I & II \\
Chemical (pH) & 6.5 & 11 \\
Thermal $\left({ }^{\circ} \mathrm{C}\right)$ & 25 & 60 \\
\hline
\end{tabular}

The chemical pretreatment consisted of controlling the $\mathrm{pH}$ at 6.5 and 11 , implementing $\mathrm{CaO}$. The thermal pretreatment was performed with an electrical resistance $(1000 \mathrm{~W}$, Pretul) to adjust the temperature of the dilution water to $25^{\circ} \mathrm{C}$ and 60 ${ }^{\circ} \mathrm{C}$. The concentration adjustment to $7 \mathrm{~g}$ TVS $\cdot \mathrm{L}^{-1}$ and $14 \mathrm{~g}$ TVS $\cdot \mathrm{L}^{-1}$, respectively, was carried out simultaneously with the thermal treatment.

\subsection{Biochemical methane potential test (BMP)}

The model for the test was an adaptation of the reaction system proposed by Cabbai et al. [24] and its construction consist of a $500 \mathrm{~mL} \operatorname{Kimax}^{\circledR}$ screw cap glass bottle (working volume $400 \mathrm{~mL}$ ) (Fig. 1). The cap was modified by incorporating a $4 \mathrm{~mm}$ diameter outlet connector, which was connected to a displacement quantification system for the biogas produced. The biogas storage vessel was made of polypropylene with a capacity of 1000 $\mathrm{mL}$, for which two $4 \mathrm{~mm}$ diameter conduits were adapted for the flow of gas and water from the system. The EU consisted of a mixture of $50 \%$ enriched inoculum and $50 \%$ pretreated residue (1:1 volume), which were then placed in a Daihan Lab Tech ${ }^{\circledR}$ model LSI-1005R incubator with a temperature control of $35{ }^{\circ} \mathrm{C} \pm 0.5$ and $60 \mathrm{rpm}$ for 32 days[25].

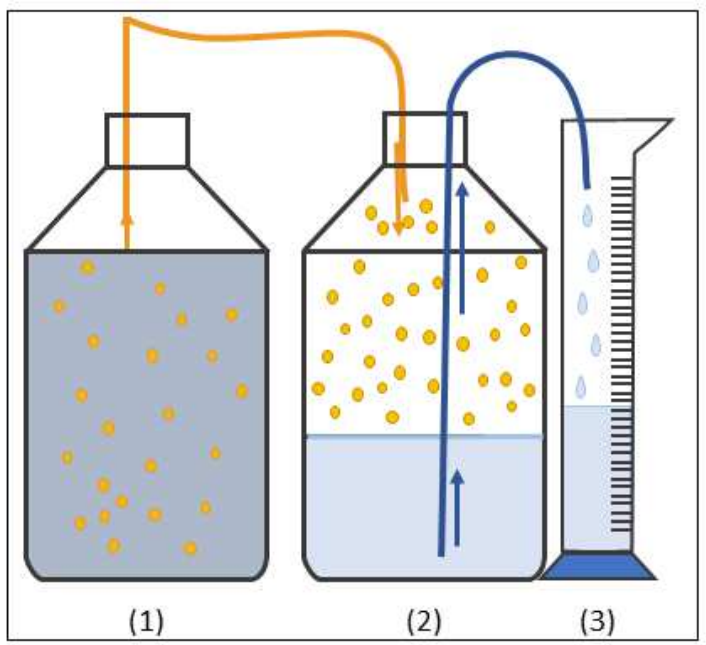

Fig. 1 Schematic diagram of BMP system construction.

The collected gas was analyzed by gas chromatography in a Buck Scientific ${ }^{\circledR}$ gas chromatograph, model $910 \mathrm{GC}$ with thermal conductivity detector (TDC) and 1-meter-long silica ss column with an external diameter of $3.17 \mathrm{~mm}$ and finger-tight junction. 
Table 3 Matrix of operation conditions for each EU.

\begin{tabular}{ccccc}
\hline EU & Grinding & $\mathrm{pH}$ & Temperature $\left({ }^{\circ} \mathrm{C}\right)$ & Concentration $\left(\mathrm{g} \mathrm{TVS} \cdot \mathrm{L}^{-1}\right)$ \\
\hline 1 & Blender (type 1) & 11 & 60 & 14 \\
2 & Blender (type 1) & 11 & 25 & 7 \\
3 & Grinder (type 2) & 6.5 & 60 & 14 \\
4 & Grinder (type 2) & 6.5 & 25 & 7 \\
5 & Blender (type 1) & 6.5 & 60 & 7 \\
6 & Blender (type 1) & 6.5 & 25 & 14 \\
7 & Grinder (type 2) & 11 & 60 & 7 \\
8 & Grinder (type 2) & 11 & 25 & \\
9 & Inoculumn & & \\
10 & Inoculum/waste 7 g TVS. $\mathrm{L}^{-1}$ & \\
11 & Inoculum/waste 14 g TVS.L $\mathrm{L}^{-1}$ & \\
\hline
\end{tabular}

\subsection{Analytical methods}

The parameters ( $\mathrm{pH}$, conductivity, alkalinity, total solids, and volatile solids) were analyzed according to Standard Methods [26]; the chemical oxygen demand, total nitrogen, and total phosphorus were determined through $\mathrm{HACH}$ methodology; the alpha ratio was analyzed according to the methodology presented by Li et al. [27]. The elemental analysis $(\mathrm{C}, \mathrm{H}, \mathrm{N}, \mathrm{S})$ was determined with a LECO $^{\circledR}$ equipment model CHN628 with external sulfur module. After 32 days, the EU was disassembled, and the content was analyzed according to Table 4. Main effects plots were carried out in Minitab $17^{\circledR}$.

\subsection{Kinetic constant}

The first-order model (Eq. 1) describes methane production in BMP tests. $B(t)$ represents the methane concentration in function of time, $t$ is the independent variable (time), $B$ is the final methane production in the system, and $k$ is the kinetic constant of methane production [28].

$$
\begin{aligned}
& B(t)=B\left(1+e^{-k t}\right) \\
& \left(\frac{\ln \left(-\frac{B(t)}{B}+1\right)}{-t}\right)=k
\end{aligned}
$$

The first-order model (Eq. 3) describes the consumption of volatile solids in BMP tests. $\mathrm{Ca}$ represents the concentration of volatile solids over a period of time, $t$ is the independent variable (time), $C a_{0}$ is the initial concentration of volatile solids in the system, and is the degradation kinetic parameter [29].

$$
\begin{aligned}
& C a=C a_{0} e^{-k t} \\
& \left(\frac{\ln \left(\frac{C a}{C a_{0}}\right)}{-t}\right)=k
\end{aligned}
$$

\section{Results and Discussion}

\subsection{Characterization of residue and inoculum}

The results from the food waste characterization and the inoculum are shown in Table 4. It can be observed that the inoculum presents the desirable characteristics for anaerobic processes [8,30]: $\mathrm{pH}$ $7.16 \pm 0.01$, an Alpha ratio higher than 0.5, TS concentration of $63 \pm 13.01 \mathrm{~g}$ TS $\cdot \mathrm{L}^{-1}$ and conductivity of $11.04 \pm 0.01 \mathrm{mS} \cdot \mathrm{cm}^{-1}$, regarding the residue, it presented an acid $\mathrm{pH}$ with a value of $4.01 \pm 0.01$, TVS concentration of $168.61 \pm 18.46$ g TVS $\cdot \mathrm{L}^{-1}$, which represents $96.83 \%$ of organic matter based on total solids [31].

The results of the waste elemental analysis are shown in Table 5, from which the C:N:P ratio of 46.5:7.4:1 was obtained, which is considered to present a minor nitrogen deficiency for carbon removal for the anaerobic processes [32]. This does not limit the anaerobic process operation.

\subsection{BMP test}

The initial $\mathrm{pH}$ of the UE was found to be within the recommended values for anaerobic processes 
Table 4 Initial characterization of inoculum and residue.

\begin{tabular}{cccc}
\hline Parameter & Units & Inoculum & Waste \\
\hline $\mathrm{pH}$ & $\mathrm{N} / \mathrm{A}$ & $7.16 \pm 0.01$ & $4.01 \pm 0.01$ \\
Conductivity & $\mathrm{mS} \cdot \mathrm{cm}^{-1}$ & $11.04 \pm 0.01$ & $11.27 \pm 1.58$ \\
Total Nitrogen & $\mathrm{g} \cdot \mathrm{L}^{-1}$ & $1.39 \pm 0.06$ & $0.50 \pm 0.14$ \\
Total Phosphorus & $\mathrm{g} \cdot \mathrm{L}^{-1}$ & $2.20 \pm 0.30$ & $1.06 \pm 0.08$ \\
COD & $\mathrm{g} \cdot \mathrm{L}^{-1}$ & $63.20 \pm 13.01$ & $187.20 \pm 31.68$ \\
Solids & $\mathrm{g} \cdot \mathrm{L}^{-1}$ & $63.00 \pm 0.31$ & $174.12 \pm 17.20$ \\
Solids & $\mathrm{g} \cdot \mathrm{L}^{-1}$ & $44.65 \pm 0.35$ & $168.61 \pm 18.46$ \\
Solids & $\mathrm{g} \cdot \mathrm{L}^{-1}$ & $10.10 \pm 11.62$ & $25.21 \pm 1.26$ \\
Alkanity & $\mathrm{g} \mathrm{CaCO} 3 \cdot \mathrm{L}^{-1}$ & $52.16 \pm 1.19$ & $\mathrm{~N} / \mathrm{D}$ \\
Alpha ratio & $\mathrm{N} / \mathrm{A}$ & $0.63 \pm 0.02$ & $\mathrm{~N} / \mathrm{D}$ \\
\hline
\end{tabular}

${ }^{\mathrm{a}}$ Chemical Oxygen Demand

Table 5 Elemental analysis of food waste.

\begin{tabular}{cc}
\hline Parameter & Weight percentage \\
\hline $\mathrm{C}$ & $52.56 \pm 0.640$ \\
$\mathrm{H}$ & $8.00 \pm 0.130$ \\
$\mathrm{~N}$ & $8.37 \pm 0.260$ \\
$\mathrm{O}$ & $29.00 \pm 0.42$ \\
$\mathrm{P}$ & $1.13 \pm 0.015$ \\
\hline
\end{tabular}

(7-8.5) [33]. This can be attributed to the inoculum's initial conditions (alpha ratio 0.63, total alkalinity $\left.52.6 \mathrm{~g} \mathrm{CaCO}_{3} \cdot \mathrm{L}^{-1}\right)$. The buffer conditions present in the inoculum helped to compensate for the acidic nature of the residue, thus maintaining an adequate $\mathrm{pH}$ for the degradation process.

Generally, the $\mathrm{pH}$ presented a decay in all the EU (Table 6). Because of the synthesis of volatile fatty acids (VFA) during anaerobic digestion, this behavior is considered typical.[27]; despite these acids, the $\mathrm{pH}$ remained within the recommended range. This can be attributed to the alpha ratio, the total alkalinity of the inoculum, and the $\mathrm{CaO}$ added in the pretreatments, which helped improve the $\mathrm{pH}$ of the waste and to maintain the digestion conditions due to the neutralization of the acid character of the waste, as well as the acids that were formed in the degradation process. Table 6 shows the alpha ratio values at the end of the test. Most of the EU, except for EU 7, 8, and 9 (inoculum blank), present values below 0.5 , indicating the consumption of buffer capacity within the system; the total alkalinity (Table 6 ) in all the systems presented a low value compared to the recommended levels $\left(13-15 \mathrm{~g} \mathrm{CaCO}_{3} \cdot \mathrm{L}^{-1}\right)$ [33]. The electrical conductivity was found to be within normal values for anaerobic processes [34, 35]. It is possible to distinguish two groups: those with values below $8 \mathrm{mS} \cdot \mathrm{cm}^{-1}$ (concentration of $7 \mathrm{~g}$ TVS $\cdot \mathrm{L}^{-1}$ ) and those with values above $8 \mathrm{mS} \cdot \mathrm{cm}^{-1}$ (Concentration of $14 \mathrm{~g}$ TVS $\cdot \mathrm{L}^{-1}$ ), indicating that the fed concentration has a direct effect on the electrical conductivity, which may be associated with the salts and seasoning implemented during the cooking processes of the food [36]. The electrical conductivity can also be considered as an estimate of the salinity of the system, according to De Vrieze et al. [37]. To avoid salinity stress, values should be kept below $30 \mathrm{mS} \cdot \mathrm{cm}^{-1}$, so conductivity was kept below these values (Table 6).

\subsection{Biogas production}

The BMP test was performed over 32 days [25]. Fig. 2 shows the accumulated daily biogas production of the EU. It is observed that the highest biogas production in the different EU occurred in the units fed with an organic load of $14 \mathrm{~g}$ TVS $\cdot \mathrm{L}^{-1}$, with productions higher than $800 \mathrm{NmL}$ of biogas; on the other hand, the EU with an organic load of $7 \mathrm{~g}$ TVS $\cdot \mathrm{L}^{-1}$ presented a production between 540 and $765 \mathrm{NmL}$ of biogas. EU 9 (inoculum blank) did not show any biogas production. According to Jiang et al. [38] and Park et al. [39], the amount of available feed is a key factor for the maintenance of optimal conditions for the anaerobic process and biogas production. This segmentation 


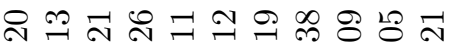

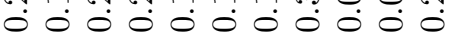
$H+H+H+H H H+H+H$

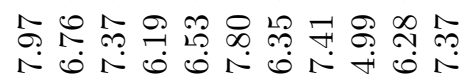

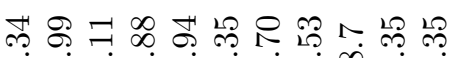

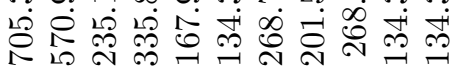
$\mathrm{H}+\mathrm{H} H \mathrm{H} H \mathrm{H}+\mathrm{H} H \mathrm{H}$ ช.

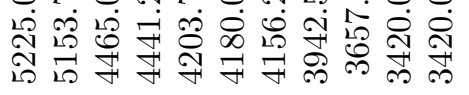

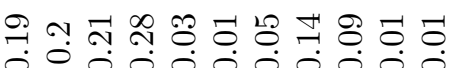
H H H H H H H H H ๙2.

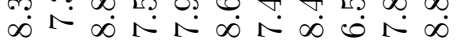

into two groups regarding the organic load presented a normal development for the conditions in which the degradation process was carried out.

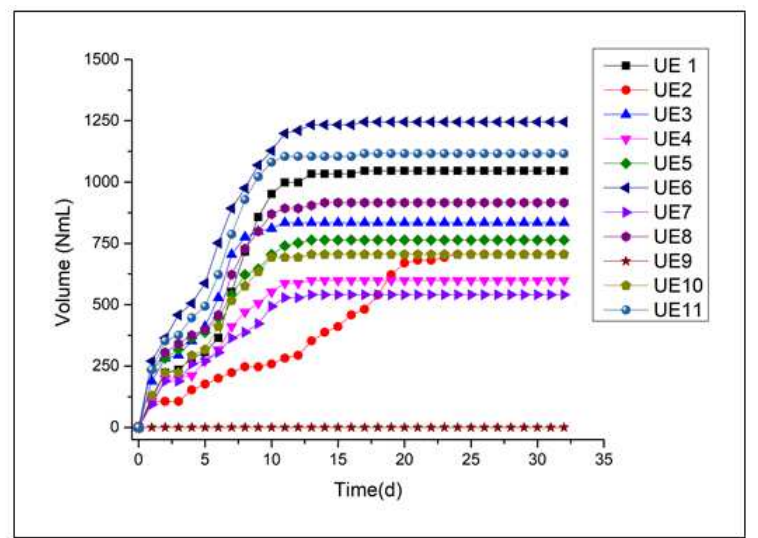

Fig. 2 Cumulative biogas production.

Fig. 3 presents the results of the main effects analysis, which indicate that grinding with a processor and the concentration of $14 \mathrm{~g}$ TVS $\cdot \mathrm{L}^{-1}$ are the most important factors for biogas production, followed by the chemical treatment, $\mathrm{pH} 11$ and the temperature of $60^{\circ} \mathrm{C}$, which had the least effect on biogas production.

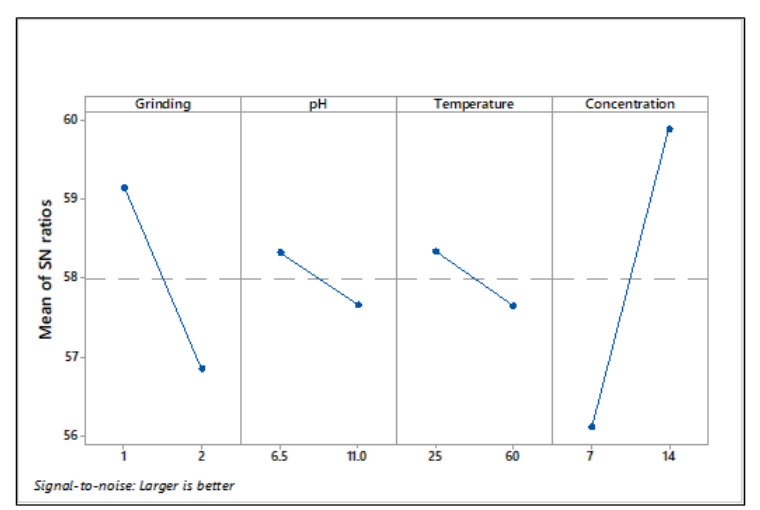

Fig. 3 Main effects plot for the signal-to-noise factor for cumulative biogas volume.

\subsection{Biogas composition}

Fig. 4 presents the composition from the biogas obtained in all the EU by chromatographic analysis. In general, it is observed that most of the 
EU presented a biogas production with a composition higher than $60 \% \mathrm{CH}_{4}$, except for EU 3, 6,8 , and 11 , which presented methane concentration lower than $50 \% \mathrm{v} / \mathrm{v}$. Those units were the ones fed with a concentration of $14 \mathrm{~g}$ TVS $\cdot \mathrm{L}^{-1}$. Another recurrent factor in this group were the low $\mathrm{pH}$ conditions (6.5), therefore, low methane concentration is associated with low $\mathrm{pH}$ operating conditions; Fig. 5 shows the main effects graph for methane percentage, which indicates that a fed concentration of $14 \mathrm{~g}$ TVS $\cdot \mathrm{L}^{-1}$ and low $\mathrm{pH}$ conditions (6.5) has a minor effect on the increase of methane concentration. When $\mathrm{CaO}$ comes in contact with water, through the hydration reaction, $\mathrm{CaO}$ is transformed to $\mathrm{Ca}(\mathrm{OH})_{2}$ (Eq. 3), and when dissolved into the system, according to Sebola et al. [40], it functions as a caustic solvent that captures the $\mathrm{CO}_{2}$ present in the water (eq. 4). Likewise, when $\mathrm{Ca}(\mathrm{OH})_{2}$ comes in contact with $\mathrm{H}_{2} \mathrm{~S}$ it generates the formation of sulfur salts (Eq. 5) [41]; therefore, it is possible to affirm that the $\mathrm{Ca}(\mathrm{OH})_{2}$ present in the system helps with the biogas upgrading process. This can be observed through the EUs with chemical treatment and a $\mathrm{pH} 11$, which are the ones that presented a low $\mathrm{CO}_{2}$ composition according to the corresponding fed concentration. As an example, we can take EU 1 which presents a methane concentration higher than $60 \% \mathrm{v} / \mathrm{v}$, despite having a fed concentration of $14 \mathrm{~g}$ TVS $\cdot \mathrm{L}^{-1}$.

$$
\begin{gathered}
\mathrm{CaO}(s)+\mathrm{H}_{2} \mathrm{O}(\mathrm{l}) \rightarrow \mathrm{Ca}(\mathrm{OH})_{2}(a c) \\
\mathrm{CO}_{2}(a c)+\mathrm{Ca}(\mathrm{OH})_{2}(a c) \rightarrow \mathrm{CaCO}_{3}(s)+\mathrm{H}_{2} \mathrm{O}(l) \\
\mathrm{H}_{2} \mathrm{~S}(a c)+\mathrm{Ca}(\mathrm{OH})_{2}(a c) \rightarrow \mathrm{CaS}(a c)+4 \mathrm{H}_{2} \mathrm{O}(l)
\end{gathered}
$$

The EU with a feed concentration of $14 \mathrm{~g}$ TVS $\cdot \mathrm{L}^{-1}$ presented a higher methane production. This is explained based on the amount of organic matter available for consumption. When organic matter is degraded, it's transformed into VFA, which are later consumed to carry out the formation of $\mathrm{CH}_{4}, \mathrm{CO}_{2}$, and $\mathrm{H}_{2}$. As mentioned before, the segregation into two groups according to the volume of biogas produced is directly related to the organic matter workload: the greater the amount of food available the greater the $\mathrm{CH}_{4}$, $\mathrm{CO}_{2}$, and $\mathrm{H}_{2}$ generation. Remembering that the $\mathrm{Ca}(\mathrm{OH})_{2}$ present in the solution works as a caustic solvent that allows the capture of acid products

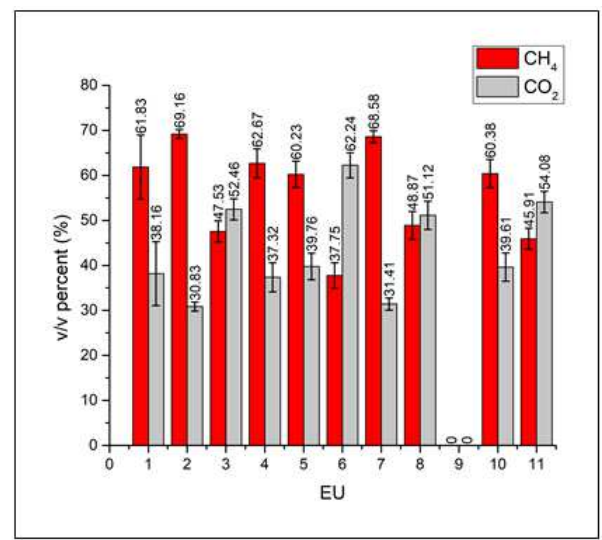

Fig. 4 Composition of biogas in the EU.

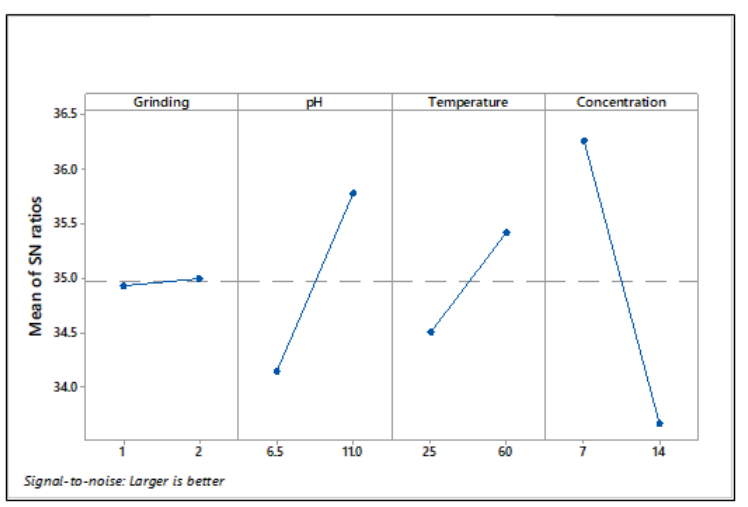

Fig. 5 Main effects plot for the SN factor biogas methane percentage.

such as $\mathrm{CO}_{2}$, and $\mathrm{H}_{2} \mathrm{~S}$, this improves the quality of the biogas by increasing the concentration of $\mathrm{CH}_{4}$. As the volume of $\mathrm{CO}_{2}$ increases, the consumption of $\mathrm{Ca}(\mathrm{OH})_{2}$ as a caustic solvent to retain this gas increases. As its consumption increases, it loses efficiency in $\mathrm{CO}_{2}$ capture, as a result when working with high feed concentrations it is possible to expect that $\mathrm{CO}_{2}$ production will be higher, and at lower feed concentrations the retention of the $\mathrm{CO}_{2}$ in the system will improve and the quality of the biogas generated will increase. On the other hand, EU 6 presented the highest $\mathrm{CO}_{2}$ production, followed by EU 11 and 3, all with a concentration above $50 \%$; the same EU correspond to a pretreatment of $\mathrm{pH} 6.5$ which evidences that the addition of $\mathrm{CaO}$ to the system confers the conditions to capture part of the $\mathrm{CO}_{2}$ generated in the anaerobic processes [40]. 


\subsection{Cumulative methane production}

Fig. 6 shows the cumulative production volumes of biogas, $\mathrm{CH}_{4}$, and $\mathrm{CO}_{2}$ obtained in the EU. The EU that presented the best $\mathrm{CH}_{4}$ production was EU 1 ( $646 \mathrm{NmL})$ followed by EU 11, 2, 6, 8, and 5 . EU 1, 6, 8, and 11 correspond to the feed concentration of $14 \mathrm{~g}$ TVS $\cdot \mathrm{L}^{-1}$, and EU 1, 2, 5, and 6 are consistent with a type I (blender) mechanical pretreatment; based on this, it is considered that feed concentration and grinding type are key factors in $\mathrm{CH}_{4}$ production; grinding with a blender improves the solubilization processes of organic matter, and combined with a high organic load, indicates that the amount of organic matter readily available is key for $\mathrm{CH}_{4}$ production [42], therefore the amount of organic matter readily available is a key factor for $\mathrm{CH}_{4}$ production.

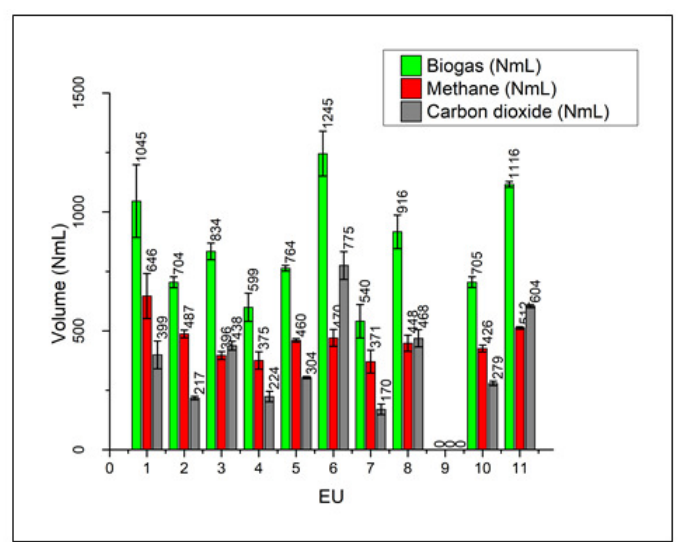

Fig. 6 Final production of Biogas, methane, and carbon dioxide in the EUs.

Subsequently, the main effects graph for $\mathrm{CH}_{4}$ production (Fig. 7) indicates that grinding and concentration are the factors that have the greatest effect on the increase of $\mathrm{CH}_{4}$ production; in the case of grinding, it is shown that doing so with a blender has the greatest effect on $\mathrm{CH}_{4}$ production. Regarding feed concentration, it is indicated that a concentration of $14 \mathrm{~g} \mathrm{SSV} \cdot \mathrm{L}^{-1}$ presents the best effect in the increase of $\mathrm{CH}_{4}$ production for this case.

\subsection{Methane yield}

Fig. 8 shows the obtained yields of $\mathrm{CH}_{4}$ and $\mathrm{CO}_{2}$. In the case of $\mathrm{CH}_{4}$ production, the $\mathrm{EU}$ with the best yields were EU 1 and 6, with values of 65.92

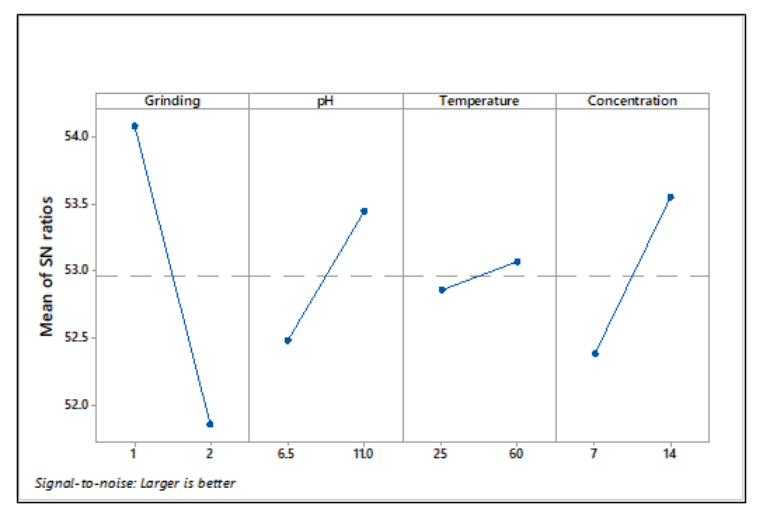

Fig. 7 Main effects plot for the SN ratio for cumulative methane production.

NmL $\cdot g{ }^{-1}$ TVS y $62.87 \mathrm{NmL} \cdot g{ }^{-1}$ TVS, respectively. These units are consistent with the feed concentration of $14 \mathrm{~g}$ TVS $\cdot \mathrm{L}^{-1}$ and grinding type I (blender). As mentioned previously, the feed concentration and particle size are key factors for $\mathrm{CH}_{4}$ production, however, the performance of $\mathrm{EU}$ 1 differs with previous studies of the application of food waste pretreatments: Naran et al. [43] obtained yields that were around $137.1 \mathrm{~mL} \mathrm{CH}_{4}$ $\cdot \mathrm{g}^{-1} \mathrm{VSS}$ and $206.4 \mathrm{~mL} \mathrm{CH}_{4} \cdot \mathrm{g}^{-1} \mathrm{VSS} 137.1 \mathrm{~mL}$ $\mathrm{CH}_{4} \cdot \mathrm{g}^{-1} \mathrm{VSS}$ y $206.4 \mathrm{~mL} \mathrm{CH} 4 \cdot \mathrm{g}^{-1} \mathrm{VSS}$, indicating that the yields obtained in this study were lower than previous studies. On the other hand, the EU with the highest $\mathrm{CO}_{2}$ yields were units 6 and 11 , resulting in $103.63 \mathrm{NmL} \cdot \mathrm{g}^{-1}$ TVS y $57.66 \mathrm{NmL}$ $\cdot \mathrm{g}^{-1}$ TVS, which concur with the feed concentration of $14 \mathrm{~g}$ TVS $\cdot \mathrm{L}^{-1}$. Another common factor is the $\mathrm{pH}, \mathrm{EU} 6$ presented a pretreatment with a $\mathrm{pH}$ of 6.5, and EU 11 did not present any modification, maintaining its acid nature. Based on this, it is possible to attribute the high $\mathrm{CO}_{2}$ release in the biogas to the poor or null presence of alkaline agents in the system, which could serve as caustic solvents for $\mathrm{CO}_{2}$ capture in the system.

Fig. 9 shows the main effects analysis for methane yield, in which it is observed that the levels that present a greater effect to increase it are grinding type I (blender), $\mathrm{pH} 11$, temperature $25^{\circ} \mathrm{C}$, and an organic load of $14 \mathrm{~g}$ TVS consumed $\cdot \mathrm{L}^{-1}$. Grinding, $\mathrm{pH}$, and feed concentration are the most important factors for yield improvement, EU 1 being the one that groups these three factors with their respective levels, differing only in the pretreatment temperature. 


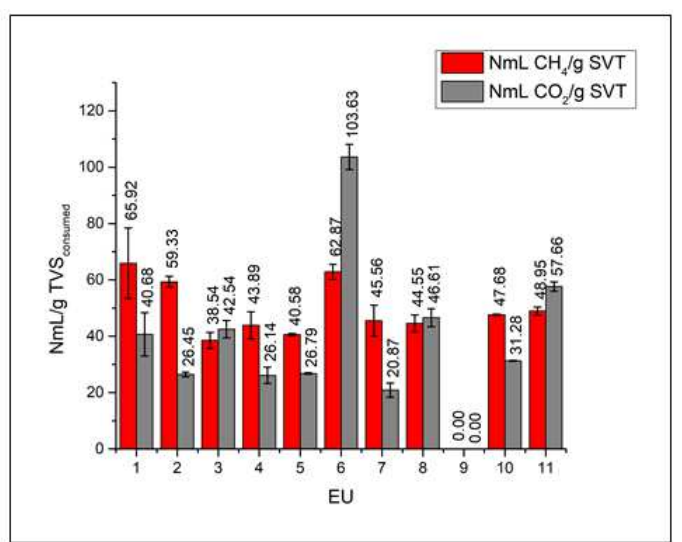

Fig. 8 Methane yield per gram of TVS consumed in the EU.

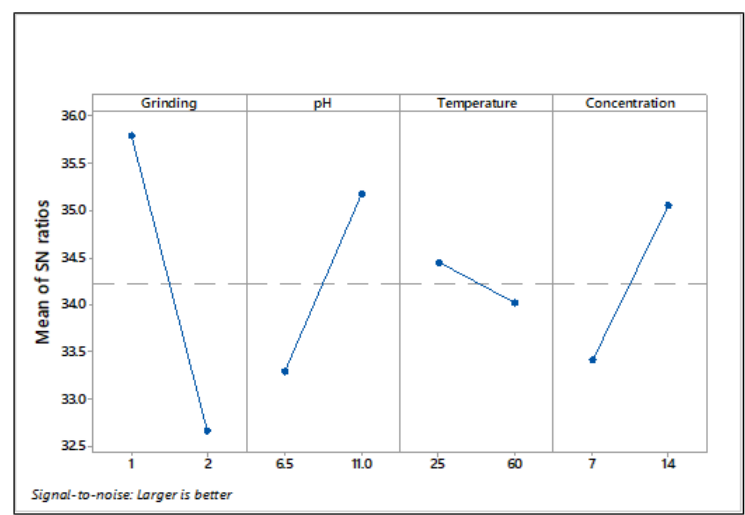

Fig. 9 Main effects plot for methane yield.

Fig. 10 shows the TVS remotion percentage (removal). The best removals were obtained in EU 5,10 , and 11 with removals of $64.10 \%, 63.96 \% \mathrm{y}$ $59.28 \%$ respectively. On the other hand, the EU with the lowest remotion was EU 1 with a remotion of $40.78 \%$. Based on this, it is considered that the best conditions for organic matter remotion are those implemented in EU 5 (grinding: blender, $\mathrm{pH}$ : 6.5 , temperature: $60^{\circ} \mathrm{C}$, feed concentration: 7 g TVS $\cdot \mathrm{L}^{-1}$.

According to the exposure by Da Silva et al. [28], rapidly biodegradable substrates present a degradation kinetic constant $(K)$ value higher than $0.2 \mathrm{~d}^{-1}$. The $K$ value in all EU presents a value above this, both for TVS consumption and methane generation, indicating that food waste is a rapidly biodegradable substrate. When examining the results presented in Table 7 , the kinetic values obtained by EU 3 ( $K_{\text {degradation }} 1.1$

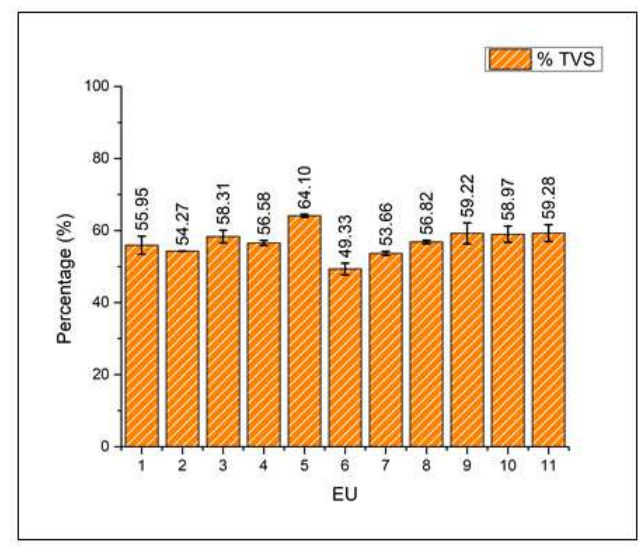

Fig. 10 Percentage of TVS remotion

$\mathrm{d}^{-1}, K_{\text {generation }} 0.86 \mathrm{~d}^{-1}$ ) stand out, since they present the highest TVS degradation rate, as well as the best methane production rate. However, the yields TVS consumed indicate that this unit presented a lower production percentage and methane yield (396.45 $\mathrm{NmL} \mathrm{CH}_{4}, 47.53 \% \mathrm{CH}_{4}$, $\left.38.54 \mathrm{NmL} \mathrm{CH}_{4} \cdot \mathrm{g}^{-1} \mathrm{TVS}\right)$ than those obtained by EU 1, which, despite presenting lower kinetic values ( $K_{\text {degradation }} 0.7 \mathrm{~d}^{-1}, K_{\text {generation }} 0.58 \mathrm{~d}^{-1}$ ), obtained higher accumulated methane volume, higher methane percentage in the biogas and therefore, better methane yields $(646.49 \mathrm{NmL}$ $\left.\mathrm{CH}_{4}, 61.83 \% \mathrm{CH}_{4}, 65.92 \mathrm{NmL} \mathrm{CH}_{4} \cdot \mathrm{g}^{-1} \mathrm{TVS}\right)$. This is explained based on the rate of VFA generation in the system: with a higher rate of TVS consumption, the generation of VFA is higher, when the system presents an accumulation of VFA, they generate a $\mathrm{pH}$ decompensation within the system, which leads to the destabilization of the anaerobic process thus reducing the methane production in the process. The acetogenesis and methanogenesis stages are affected by changes in $\mathrm{pH}$ which leads to lower methane production[17, 44]. This corroborates that in the case of EU 1, the pretreatment system generated the conditions ( $\mathrm{pH}$, alpha ratio, alkalinity, waste availability) to maintain the system able for a long time, improving the methane production process. Additionally, it is considered convenient to evaluate the concentration of $\mathrm{NaCl}$ in the food waste, since, as explained by Zhao et al. [45], the $\mathrm{NaCl}$ present in the food can inhibit the methanogenic processes, decreasing the production of $\mathrm{CH}_{4}$ in the system. 


\section{Conclusions}

For this study, the application of pretreatments and the implementation of an inoculum with a high concentration of alkalinity increased the methane production obtained in the anaerobic digestion process of the food waste; by increasing the bioavailability of the substrate with the grinding process, improving the solubility with the thermal treatment and increasing the buffer conditions of the system by means of the chemical agent $\left(\mathrm{Ca}(\mathrm{OH})_{2}\right)$, it was able to improve the overall degradation of the substrate, and consequently increase the methane output of the system. In the best conditions (EU 1, grinding type I, $\mathrm{pH} 11$, temperature $60{ }^{\circ} \mathrm{C}$, and feed concentration of $14 \mathrm{~g}$ TVS $\cdot \mathrm{L}^{-1}$ ), a $34.66 \%$ improvement in the yield was achieved, which can be attributed to the general enhancement of the conditions described above; however, being a Bach type test, it is necessary to perform an evaluation in a continuous or seimicontinuous regime to determine the viability of the process.

Acknowledgments. The authors greatly appreciate the financial support of the Coordinacion de la Investigación Científica de la Universidad Michoacana de San Nicolas de Hidalgo (CIC-UMSNH, México). Thanks to Consejo Nacional de Ciencia y Tecnología (CONACyT, Mexico) for the scholarship (701706) received during the development of this work. The authors appreciate the support of Sandra Cecilia Cerda Flores for the language reappraisal.

\section{References}

[1] Tyagi V.K., Fdez-Güelfo L.A., Zhou Y., Álvarez-Gallego C.J., Garcia L.I.R., $\mathrm{Ng}$ W.J., Anaerobic co-digestion of organic fraction of municipal solid waste (OFMSW): Progress and challenges, Renew. Sustain. Energy Rev. 93 (2018) 380-399. https://doi.org/10.1016/j.rser.2018.05.051.

[2] Zhang X.B., Xu J., Optimal policies for climate change: A joint consideration of $\mathrm{CO} 2$ and methane, Appl. Energy. 211 (2018) 1021-1029. https://doi.org/10.1016/j.apenergy.2017.10.067. 
[3] Saunois M., Jackson R.B., Bousquet P., Poulter B., Canadell J.G., The growing role of methane in anthropogenic climate change, Environ. Res. Lett. 11 (2016). https://doi.org/10.1088/17489326/11/12/120207.

[4] Belgiorno V., Panza D., Russo L., Amodio V., Cesaro A., Alternative stabilisation options of mechanically sorted organic fraction from municipal solid waste prior to landfill disposal, Int. J. Environ. Eng. 3 (2011) 318. https://doi.org/10.1504/ijee.2011.041356.

[5] United Nations Environment Programme, Food Waste Index Report 2021, 2021.

[6] Maina S., Kachrimanidou V., Koutinas A., A roadmap towards a circular and sustainable bioeconomy through waste valorization, Curr. Opin. Green Sustain. Chem. $8 \quad$ (2017) 18-23. https://doi.org/10.1016/j.cogsc.2017.07.007.

[7] Dahiya S., Kumar A.N., Shanthi Sravan J., Chatterjee S., Sarkar O., Mohan S.V., Food waste biorefinery: Sustainable strategy for circular bioeconomy, Bioresour. Technol. 248 (2018) 2-12. https://doi.org/10.1016/j.biortech.2017.07.176.

[8] Braguglia C.M., Gallipoli A., Gianico A., Pagliaccia P., Anaerobic bioconversion of food waste into energy: A critical review, Bioresour. Technol. 248 (2018) 37-56. https://doi.org/10.1016/j.biortech.2017.06.145.

[9] Bayard R., Liu X., Benbelkacem H., Buffiere P., Gourdon R., Can Biomethane Potential (BMP) Be Predicted from Other Variables Such As Biochemical Composition in Lignocellulosic Biomass and Related Organic Residues?, Bioenergy Res. 9 (2016) 610-623. https://doi.org/10.1007/s12155-015-9701-3.

[10] Li L., Peng X., Wang X., Wu D., Anaerobic digestion of food waste: A review focusing on process stability, Bioresour. Technol. 248 (2018) 20-28. https://doi.org/10.1016/j.biortech.2017.07.012.
[11] Parthiba Karthikeyan O., Trably E., Mehariya S., Bernet N., Wong J.W.C., Carrere H., Pretreatment of food waste for methane and hydrogen recovery: A review, Bioresour. Technol. 249 (2018) 1025-1039. https://doi.org/10.1016/j.biortech.2017.09.105.

[12] Khor W.C., Rabaey K., Vervaeren H., Low temperature calcium hydroxide treatment enhances anaerobic methane production from (extruded) biomass, Bioresour. Technol. 176 (2015) 181-188. https://doi.org/10.1016/j.biortech.2014.11.037.

[13] Civelek Yoruklu H., Korkmaz E., Manav Demir N., Ozkaya B., Demir A., The impact of pretreatment and inoculum to substrate ratio on methane potential of organic wastes from various origins, J. Mater. Cycles Waste Manag. 20 (2018) 800-809. https://doi.org/10.1007/s10163-017-0641-1.

[14] Cesaro A., Belgiorno V., Pretreatment methods to improve anaerobic biodegradability of organic municipal solid waste fractions, Chem. Eng. J. 240 (2014) 24-37. https://doi.org/10.1016/j.cej.2013.11.055.

[15] Ariunbaatar J., Panico A., Esposito G., Pirozzi F., Lens P.N.L., Pretreatment methods to enhance anaerobic digestion of organic solid waste, Appl. Energy. 123 (2014) 143-156. https://doi.org/10.1016/j.apenergy.2014.02.035.

[16] Agbor V.B., Cicek N., Sparling R., Berlin A., Levin D.B., Biomass pretreatment: Fundamentals toward application, Biotechnol. Adv. 29 (2011) 675-685. https://doi.org/10.1016/j.biotechadv.2011.05.005.

[17] Latif M.A., Ahmad A., Ghufran R., Wahid Z.A., Effect of temperature and organic loading rate on upflow anaerobic sludge blanket reactor and $\mathrm{CH} 4$ production by treating liquidized food waste, Environ. Prog. Sustain. Energy. 31 (2012) 114-121. https://doi.org/10.1002/ep.10540.

[18] Xu F., Li Y., Ge X., Yang L., Li Y., Anaerobic digestion of food waste - 
Challenges and opportunities, Bioresour. Technol. 247 (2018) 1047-1058. https://doi.org/10.1016/j.biortech.2017.09.020.

[19] Mirmohamadsadeghi S., Karimi K., Tabatabaei M., Aghbashlo M., Biogas production from food wastes: A review on recent developments and future perspectives, Bioresour. Technol. Reports. 7 (2019) 100202. https://doi.org/10.1016/j.biteb.2019.100202.

[20] Kondusamy D., Kalamdhad A.S., Pretreatment and anaerobic digestion of food waste for high rate methane production - A review, J. Environ. Chem. Eng. 2 (2014) 1821-1830. https://doi.org/10.1016/j.jece.2014.07.024.

[21] Parra-Orobio B.A., Donoso-Bravo A., TorresLozada P., Pre-dimensioning of Small-Scale Anaerobic Reactors of Food Waste Through Biochemical Methane Potential Assays and Kinetic Models, Bioenergy Res. (2021). https://doi.org/10.1007/s12155-021-10291-3.

[22] Parra-Orobio B.A., Donoso-Bravo A., Ruiz-Sánchez J.C., Valencia-Molina K.J., Torres-Lozada P., Effect of inoculum on the anaerobic digestion of food waste accounting for the concentration of trace elements, Waste Manag. 71 (2018) 342-349. https://doi.org/10.1016/j.wasman.2017.09.040.

[23] Peu P., Brugère H., Pourcher A.M., Kérourédan M., Godon J.J., Delgenès J.P., Dabert P., Dynamics of a pig slurry microbial community during anaerobic storage and management, Appl. Environ. Microbiol. 72 (2006) 3578-3585. https://doi.org/10.1128/AEM.72.5.35783585.2006.

[24] Cabbai V., Ballico M., Aneggi E., Goi D., BMP tests of source selected OFMSW to evaluate anaerobic codigestion with sewage sludge, Waste Manag. 33 (2013) 1626-1632. https://doi.org/10.1016/j.wasman.2013.03.020.

[25] Filer J., Ding H.H., Chang S., Biochemical Methane Potential (BMP) Assay Method for Anaerobic Digestion Research, Water. 11 (2019). https://doi.org/10.3390/w11050921.
[26] American Public Health Association, American Water Works Association, Water Environment Federation, Standar Methods for the examination of water and wastewater, Stand. Methods Exam. Water Waste Water 20th Ed. (1998) 3-104. https://www.standardmethods.org/.

[27] Li D., Ran Y., Chen L., Cao Q., Li Z., Liu X., Instability diagnosis and syntrophic acetate oxidation during thermophilic digestion of vegetable waste, Water Res. 139 (2018) 263-271. https://doi.org/10.1016/j.watres.2018.04.019.

[28] Da Silva C., Astals S., Peces M., Campos J.L., Guerrero L., Biochemical methane potential (BMP) tests: Reducing test time by early parameter estimation, Waste Manag. 71 (2018) 19-24. https://doi.org/10.1016/j.wasman.2017.10.009.

[29] Texier A.C., Gomez J., Settleability and kinetics of a nitrifying sludge in a sequencing batch reactor, Can. J. Microbiol. 50 (2004) 943-949. https://doi.org/10.1139/w04-078.

[30] De Vrieze J., Gildemyn S., VilchezVargas R., Jáuregui R., Pieper D.H., Verstraete W., Boon N., Inoculum selection is crucial to ensure operational stability in anaerobic digestion, Appl. Microbiol. Biotechnol. 99 (2015) 189-199. https://doi.org/10.1007/s00253-014-6046-3.

[31] Fisgativa H., Tremier A., Dabert P., Characterizing the variability of food waste quality: A need for efficient valorisation through anaerobic digestion, Waste Manag. 50 (2016) 264-274. https://doi.org/10.1016/j.wasman.2016.01.041.

[32] Hussain A., Kumar P., Mehrotra I., Nitrogen and phosphorus requirement in anaerobic process: A review, Environ. Eng. Manag. J. 14 (2015) 769-780. https://doi.org/10.30638/eemj.2015.086.

[33] Tchobanoglous G., Burton F.L., Stensel H.D., Waste water engineering treatment and reuse, 4th ed. Ta, Metcalf Eddy, Inc. (2003). 
[34] Marín-Peña O., Alvarado-Lassman A., Vallejo-Cantú N.A., Juárez-Barojas I., Rodríguez-Jarquín J.P., Martínez-Sibaja A., Electrical conductivity for monitoring the expansion of the support material in an anaerobic biofilm reactor, Processes. 8 (2020). https://doi.org/10.3390/pr8010077.

[35] Proulx C.L., Kilgour B.W., Francis A.P., Bouwhuis R.F., Hill J.R., Using a conductivity-alkalinity relationship as a tool to identify surface waters in reference condition across Canada, Water Qual. Res. J. Canada. 53 (2018) 231-240. https://doi.org/10.2166/wqrj.2018.030.

[36] Zhao J., Liu Y., Wang D., Chen F., Li X., Zeng G., Yang Q., Potential impact of salinity on methane production from food waste anaerobic digestion, Waste Manag. $67 \quad$ (2017) 308-314. https://doi.org/10.1016/j.wasman.2017.05.016.

[37] De Vrieze J., Christiaens M.E.R., Walraedt D., Devooght A., Ijaz U.Z., Boon N., Microbial community redundancy in anaerobic digestion drives process recovery after salinity exposure, Water Res. 111 (2017) 109-117. https://doi.org/10.1016/j.watres.2016.12.042.

[38] Jiang J., He S., Kang X., Sun Y., Yuan Z., Xing T., Guo Y., Li L., Effect of Organic Loading Rate and Temperature on the Anaerobic Digestion of Municipal Solid Waste: Process Performance and Energy Recovery, Front. Energy Res. 8 (2020) 1-10. https://doi.org/10.3389/fenrg.2020.00089.

[39] Park J., Shin W., Shi W., Jun H., Changes of Bacterial Communities in an Anaerobic Digestion and a BioElectrochemical Anaerobic, Energies. (2019). https://doi.org/10.3390/en12152958

[40] Abdeen F.R.H., Mel M., Jami M.S., Ihsan S.I., Ismail A.F., A review of chemical absorption of carbon dioxide for biogas upgrading, Chinese J. Chem. Eng. 24 (2016) 693-702. https://doi.org/10.1016/j.cjche.2016.05.006.

[41] Campuzano-Calderón O., Estudio de la remoción de sulfuro de hidrógeno y de dióxido de carbono presente en el biogás, por medio de un reactor de columna de burbujeo operado a baja presión, (2017).

[42] Sebola M., Tesfagiorgis H., Muzenda E., Effect of particle size on anaerobic digestion of different feedstocks, South African J. Chem. Eng. 20 (2015) 11-26.

[43] Naran E., Toor U.A., Kim D.J., Effect of pretreatment and anaerobic co-digestion of food waste and waste activated sludge on stabilization and methane production, Int. Biodeterior. Biodegrad. 113 (2016) 17-21. https://doi.org/10.1016/j.ibiod.2016.04.011.

[44] Hussain A., Filiatrault M., Guiot S.R., Acidogenic digestion of food waste in a thermophilic leach bed reactor: Effect of $\mathrm{pH}$ and leachate recirculation rate on hydrolysis and volatile fatty acid production, Bioresour. Technol. 245 (2017) 1-9. https://doi.org/10.1016/j.biortech.2017.08.130.

[45] Zhao J., Liu Y., Wang D., Chen F., Li X., Zeng G., Yang Q., Potential impact of salinity on methane production from food waste anaerobic digestion, Waste Management, 67 (2017) 308-314, https://doi.org/10.1016/j.wasman.2017.05.016.

\section{Statements \& Declarations}

This work was supported by Consejo Nacional de Ciencia y Tecnología (CONACyT, Mexico), author Alanis-Silva Edgar Daniel has received scholarship (701706), and Chávez-Parga Ma. Del Carmen, and Cortés José Apolinar has received research support from Coordinación de la Investigación Científica de la Universidad Michoacana de San Nicolas de Hidalgo (CIC-UMSNH, México).

\subsection{Competing Interests}

"The authors have no relevant financial or nonfinancial interests to disclose."

\subsection{Author Contributions}

All authors contributed to the study conception and design. Material preparation, data collection 
and analysis were performed by Edgar Daniel Alanis Silva, Ma. Del Carmen Chávez Parga and José Apolinar Cortés. The first draft of the manuscript was written by Edgar Daniel Alanis Silva and all authors commented on previous versions of the manuscript. All authors read and approved the final manuscript.

\section{Appendix A Graphical Abstract}

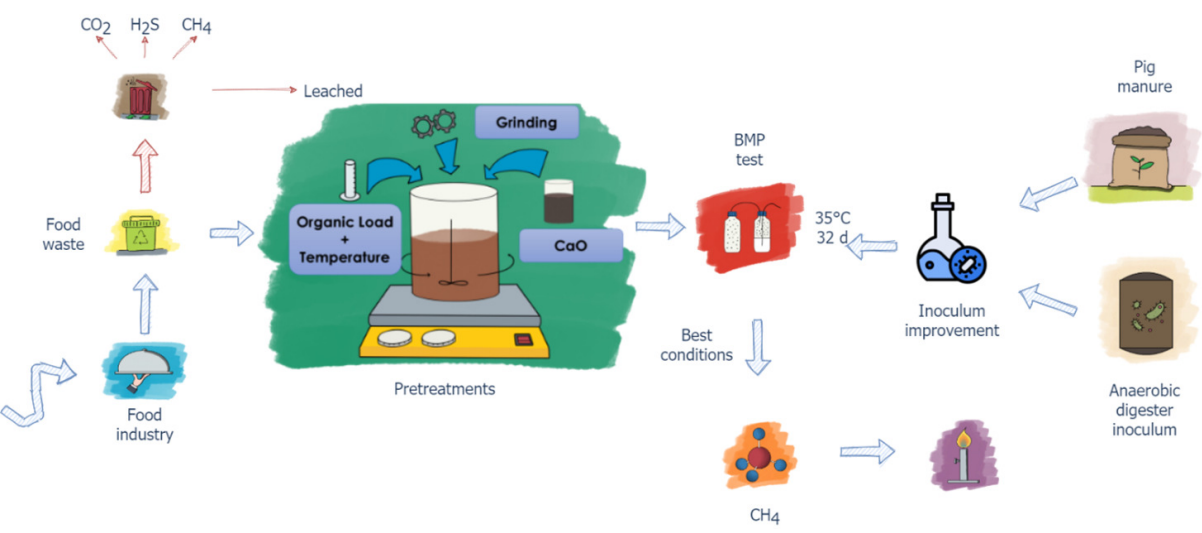

